\title{
PERBANDINGAN PENGARUH AIR KELAPA DAN MINUMAN ISOTONIK TERHADAP TINGKAT HIDRASI ATLET CABANG OLAHRAGA BOLA BASKET
}

\author{
Siska Triana Budiman', Hamidie Ronald Daniel Ray ${ }^{1,2}$ \\ ${ }^{I}$ Pendidikan Kesehatan dan Rekreasi, Universitas Pendidikan Indonesia, Bandung, Indonesia; \\ ${ }^{2}$ Faculty of Human Science, Kanazawa University Japan
}

\begin{abstract}
The purpose of this research was to find out the comparison and the effect of coconut water and isotonic drink on hydration status, to reduce anaerobic muscle fatigue and to anticipating blood sugar level increase of basketball athletes. This is quasy experimental research and use a pretest and posttest control group desain. The subject of this research are 18 basketball athletes from UPI's basketball student activity unit with ages 19-21 years old and divided randomly into 3 groups which is 2 treatment groups and control group. The subject given intervention coconut water, $250 \mathrm{ml}$ of isotonic drink and placebo, it given 30 minutes before the test. The hydration status on basketball athletes is seen from the color of urine and the muscle fatigue measured by using RAST (Running-based Anaerobic Sprint Test) by calculating the value of AF (Anaerobic Fatigue) and blood sugar levels is measured using Autocheck measuring instrument. The result of this research identified that mostly basketball athletes are get dehydration, There is a significant effect on the status of fatigue index according to the type of coconut water and isotonic drink, and also there is a significant difference in the Glicemia level of basketball athletes according to the type of drink.
\end{abstract}

Keywords: hydration status, coconut water, isotonic drink, fatigue index, glicemia level

Korespondensi: Siska Triana Budiman, E-mail:Siskatrianabudiman24@gmail.com, Program Studi Ilmu Keolahragaan Departemen Pendidikan Kesehatan dan Rekreasi Fakultas Pendidikan Olahraga dan KesehatanUniversitas Pendidikan Indonesia, Jl. Dr. Setiabudhi No 299 Bandung 


\section{PENDAHULUAN}

Permainan bola basket diciptakan oleh seorang Amerika pada tahun 1891 yang bernama DR. James A. Naismith. Bola basket dimainkan oleh dua regu. Masing-masing regu terdiri dari lima orang pemain. Setiap regu berusaha memasukkan bola ke dalam ring basket lawan dan mencegah lawan untuk memasukkan bola atau membuat angka. Bola boleh digelindingkan atau dipantulkan ke segala arah sesuai dengan peraturan. Permainan bola basket mempunyai tujuan memasukkan bola sebanyak mungkin ke basket (keranjang) lawan, serta menahan lawan agar jangan memasukkan bola ke basket (keranjang) sendiri dengan cara lempar tangkap, menggiring, dan menembak ${ }^{1}$. Intensitas yang tinggi pada olahraga basket mengakibatkan para atletnya sering mengalami kelelahan sebelum pertandingan selesai. Menurut $\mathrm{Manz}^{2}$, kelelahan terjadi akibat banyaknya keringat yang keluar saat pertandingan dan tidak diimbangi dengan konsumsi cairan yang cukup untuk menjaga keseimbangan cairan tubuh sehingga dapat meningkatkan resiko dehidrasi. Dehidrasi adalah kehilangan cairan tubuh yang berlebihan karena penggantian cairan yang tidak cukup akibat asupan yang tidak memenuhi kebutuhan tubuh dan terjadi peningkatan pengeluaran air $^{3}$.

Saat berolahraga kebutuhan cairan (hydrasi) tentu akan lebih banyak dibanding dalam keadaan istirahat, oleh karena itu saat berolahraga suhu tubuh meningkat dan tubuh menjadi panas. Tubuh yang panas berusaha untuk menjadi dingin dengan cara berkeringat. Aktivitas fisik menyebabkan peningkatan tingkat metabolisme dan produksi panas, yang mengakibatkan hilangnya air dan elektrolit dan deplesi glikogen di hati dan otot ${ }^{4}$. Hidrasi diartikan sebagai keseimbangan cairan dalam tubuh dan merupakan syarat penting untuk menjamin fungsi metabolisme sel tubuh. Sementara itu, dehidrasi berarti kurangnya cairan di dalam tubuh karena jumlah yang keluar lebih besar dari jumlah yang masuk. Apabila tubuh kehilangan banyak cairan, tubuh akan mengalami dehidrasi. Ada tiga jenis dehidrasi, yaitu: (1) hypotonic adalah tubuh kehilangan larutan elektrolit (garam, kalium, klor, kalsium, dan pospat, (2) hypertronic adalah tubuh kehilangan air, dan (3) Isotonic adalah tubuh kehilangan air dan larutan elektrolit, kondisi ini paling sering terjadi. Murray mengatakan bahwa bahaya dehidrasi adalah kemampuan kognitif menurun karena sulit berkonsentrasi, risiko infeksi saluran kemih, dan terbentuknya batu ginjal, minum yang cukup dan jangan menahan air kemih adalah cara yang paling efektif untuk mencegah infeksi saluran kemih, serta menurunkan stamina dan produktivitas kerja melalui gangguan sakit kepala, lesu, kejang hingga pingsan. Kehilangan cairan lebih dari $15 \%$ akan berakibat fatal ${ }^{6}$.

Dalam melakukan olahraga maka bentuk cairan yang di konsumsi berbeda dengan jenis minuman yang biasa di konsumsi dan jenis minuman ini dikenal dengan nama minuman Olahraga (sport drink). Minuman olahraga (sport drink) adalah minuman yang di dalamnya terdiri dari air, zat gizi, dan zat terlarut untuk mendukung ergogenic ${ }^{7}$. Dibandingkan dengan air biasa, minuman yang mengandung karbohidrat dan garam (elektrolit) dapat meningkatkan kinerja ketika dikonsumsi sebelum atau selama exercise intensitas tinggi yang berlangsung setidaknya satu jam. ${ }^{8}$ Tujuan utama dari minuman olahraga adalah untuk merangsang penyerapan cairan yang cepat, pasokan karbohidrat dan zat gizi lain sebagai substrat dalam exercise, mempercepat rehidrasi, mengurangi stres fisiologis dan mendorong pemulihan setelah latihan ${ }^{7}$. Menurut Food and Agricultural Organization (1998), ada minuman yang dikonsumsi sebagai sport drink alami atau minuman olahraga yaitu air kelapa muda.Atmaja menyebutkan bahwa air buah kelapa mengandung makronutrien seperti karbohidrat, protein, dan lemak sedangkan kandungan mikronutriennya berupa mineral dan vitamin. Mineral yang terdapat dalam air kelapa antara lain kalium, kalsium, fosfor, zinc, natrium dan magnesium? Selain air putih dan air kelapa,adapula minuman Isotonic. Minuman Isotonic seperti apa yang di sampaikan BSN (1998), minuman Isotonic merupakan salah satu produk minuman ringan karbonasi atau nonkarbonasi untuk meningkatkan kebugaran, yang mengandung gula, asam sitrat, dan mineral ${ }^{10}$. Istilah Isotonic seringkali digunakan untuk larutan minuman yang memiliki nilai osmolalitas yang mirip dengan cairan tubuh (darah), sekitar 280 mosm $/ \mathrm{kg} \mathrm{H}_{2} \mathrm{O}$. minuman Isotonic juga dikenal dengan sport drink yaitu minuman yang berfungsi untuk mempertahankan cairan dan garam tubuh serta memberikan energi karbohidrat ketika melakukan aktivitas.

Berdasarkan latar belakang dan analisis masalah yang telah diungkapkan diatas, Tujuan penelitian ini bertujuan untuk menganalisa formulasi sport drink dan memberikan informasi bagi atlet dalam mengkonsumsi minuman olahraga dengan mempertimbangkan waktu, kondisi, jumlah dan jenis dari asupan cairan dan mencari perbandingan beberapa jenis sport drink 
untuk mengetahui jenis sport drinkmana yang bagus untuk menyeimbangkan tingkat hidrasi pada cabang olahraga bola basket.

\section{METODE PENELITIAN}

Dalam penelitian ini menggunakan metode Quasy Ekperiment atau eksperimen semu. Dengan bentuk desain Pre test post testcontrol group desain .Populasi adalah pemain bola basket putra tingkat perguruan tinggi yang tergabung dalam anggota UKM bola basket UPI (Universitas Pendidikan Indonesia). Dengan sampel berjumlah 18 orang menggunakan teknik pengambilan sampel yaitu Purposive sampling. Karakteristik dalam penelitian ini laki - laki berusia $19-21$, anggota aktif UKM bola basket UPI, berbadan sehat dan tidak cacat fisik.

Pengukuran Indeks Kelelahan instrumen yang di gunakan adalah RAST test (Running based Anaerobic Sprint Test). Yang bertujuan untuk mengukur kemampuan daya tahan anaerobic dan mengetahui indeks kelelahan. Indicator yang di gunakan untuk menilai kelelahan otot adalah fatigue index / indeks kelelahan .

Tabel 1. Kategorisasi Tes Indeks Kelelahan

\begin{tabular}{cc}
\hline $\begin{array}{c}\text { Nilai Indeks } \\
\text { Kelelahan }\end{array}$ & Kategori \\
\hline$>\mathbf{1 0}$ & Tinggi \\
\hline$<\mathbf{1 0}$ & Rendah \\
\hline
\end{tabular}

Sumber : 101 Elevation Test, hal 45

Nilai indeks kelelahan $\leq 10$ mengindikasikan kemampuan atlet/subjek dalam mempertahankan performa anaerobic nya (termasuk kategori tidak lelah). Nilai indeks kelelahan $\geq 10$ merupakan indikasi bahwa atlet/subjek perlu meningkatkan performa anaerobiknya dan juga meningkatkan toleransi terhadap asam laktat (termasuk kategori lelah).

Penentuan status hidrasi pada penelitian ini berdasarkan pada hasil pengujian warna urine menggunakan urine stick dan urine color chart $^{11}$. Pengambilan sampel urin dilakukan sebelum dan setelah atlet melakukan tes, kemudian urine di uji menggunakan urine stick untuk mengetahui nilai berat jenis urinenya dan warna urine disesuaikan dengan urine color chart untuk mengetahui kategori status hidrasinya. Dan untuk penentuan kadar gula darah sampel diukur kadar gula darahnya menggunakan auto check dan strips glukosa.

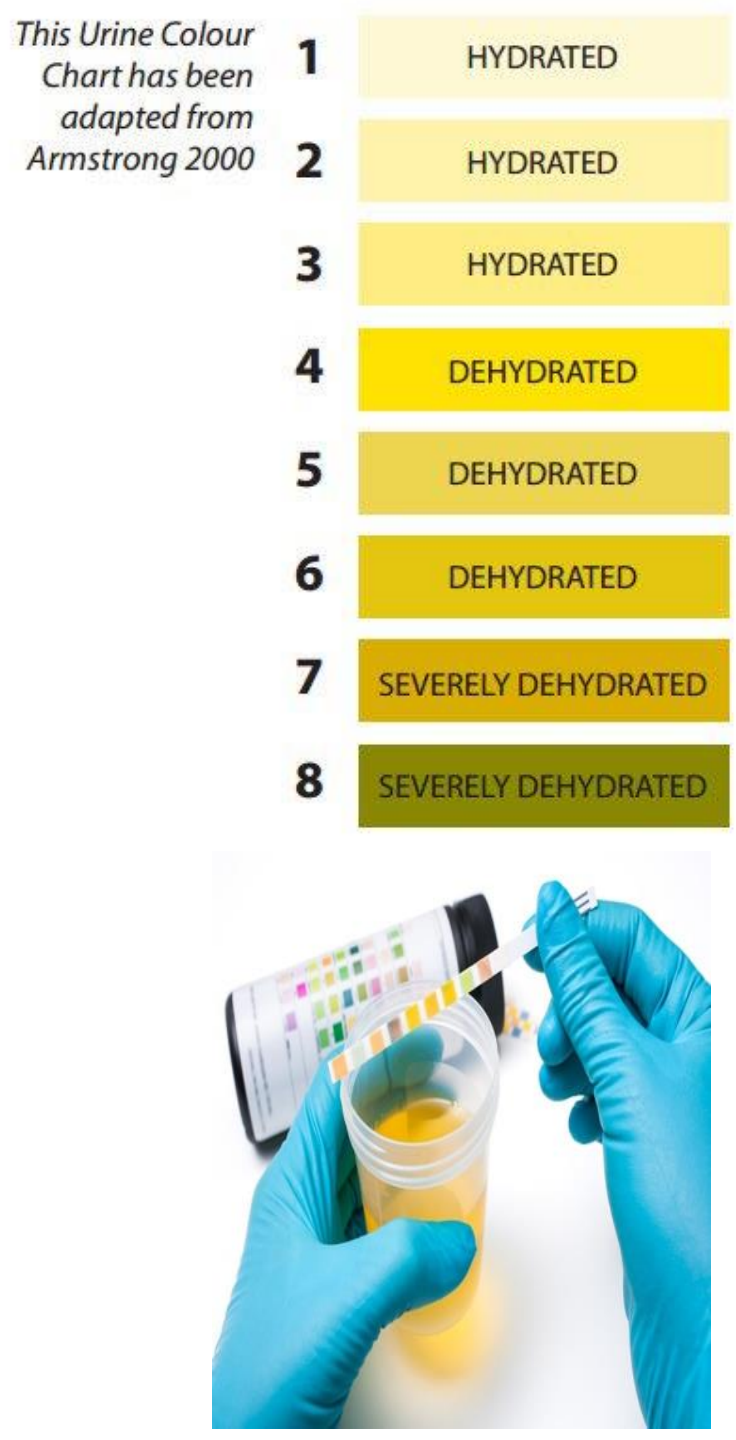

Gambar 1. Urine chart colour \& Urine stick (Armstrong, 2000)

Analisis data menggunakan program SPSS versi 22.0 for Windows. Untuk analisis dasar data dan distribusi hasil pada awal dan akhir pengukuran, parameter tes K-S dan tes homogenitas One-Way Anova. Efek dari model pemberian minuman yang diterapkan adalah di analisis menggunakan Paired Sample T-test dan One-Way Anova. Tingkat signifikansi statistik di terapkan pada $p<0,05$. 


\section{HASIL PENELITIAN}

Tabel 2.Data Hasil Status Hidrasi Kelompok Air Putih

\begin{tabular}{|c|c|c|c|c|c|c|}
\hline \multirow[t]{2}{*}{ No } & \multirow{2}{*}{$\begin{array}{l}\text { Kategori } \\
\text { Status } \\
\text { Hidrasi }\end{array}$} & \multirow{2}{*}{$\begin{array}{l}\text { Nilai } \\
\text { Berat } \\
\text { Jenis } \\
\text { Urine }\end{array}$} & \multicolumn{2}{|c|}{$\begin{array}{c}\text { Frekuensi } \\
\text { (Pre test) }\end{array}$} & \multicolumn{2}{|c|}{$\begin{array}{c}\text { Frekuensi } \\
\text { (Post test) }\end{array}$} \\
\hline & & & $\begin{array}{c}\mathbf{F} \\
(\mathbf{n})\end{array}$ & $\%$ & $\begin{array}{c}\mathbf{F} \\
(\mathbf{n})\end{array}$ & $\%$ \\
\hline 1 & Hidrasi & $\begin{array}{c}<1.010 \\
\mathrm{~g} / \mathrm{dL}\end{array}$ & 4 & 66,67 & 5 & 83,33 \\
\hline 2 & Dehidrasi & $\begin{array}{c}1.021- \\
1.030 \\
\mathrm{~g} / \mathrm{dL}\end{array}$ & 2 & 33,33 & 1 & 16,67 \\
\hline 3 & $\begin{array}{c}\text { Sangat } \\
\text { Dehidrasi }\end{array}$ & $\begin{array}{c}>1.030 \\
\text { g/dL }\end{array}$ & 0 & 0 & 0 & 0 \\
\hline & Jumlah & & 6 & 100 & 6 & 100 \\
\hline
\end{tabular}

1) Dilihat dari Tabel 2, di ketahui bahwa dari 6 orang responden penelitian kelompok Air Putih pada saat pre test, sebanyak 4 orang $(66,67 \%)$ status hidrasinya berada pada kategori hidrasi, dan sebanyak 2 orang $(33,33$ $\%)$ status hidrasinya berada pada kategori dehidrasi. Data tersebut menunjukkan bahwa mayoritas atlet anggota UKM Bola Basket UPI putra berada pada kategori hidrasi .

2) Dilihat dari Tabel 2, di ketahui bahwa dari 6 orang responden penelitian kelompok Air Putih pada saat post test, sebanyak 5 orang $(83,33 \%)$ status hidrasinya berada pada kategori hidrasi, dan sebanyak 1 orang $(16,37 \%)$ status hidrasinya berada pada kategori dehidrasi. Data tersebut menunjukkan bahwa mayoritas atlet anggota UKM Bola Basket UPI putra berada pada kategori Hidrasi.

Tabel 3. Data Hasil Status Hidrasi Kelompok Air Kelapa

\begin{tabular}{|c|c|c|c|c|c|c|}
\hline \multirow[t]{2}{*}{ No } & \multirow{2}{*}{$\begin{array}{c}\text { Kategori } \\
\text { Status } \\
\text { Hidrasi }\end{array}$} & \multirow{2}{*}{$\begin{array}{l}\text { Nilai } \\
\text { Berat } \\
\text { Jenis } \\
\text { Urine }\end{array}$} & \multicolumn{2}{|c|}{$\begin{array}{l}\text { Frekuensi } \\
\text { (Pre test) }\end{array}$} & \multicolumn{2}{|c|}{$\begin{array}{l}\text { Frekuensi } \\
\text { (Post test) }\end{array}$} \\
\hline & & & $\begin{array}{c}\mathbf{F} \\
(\mathbf{n})\end{array}$ & $\%$ & $\begin{array}{c}\mathbf{F} \\
(\mathbf{n})\end{array}$ & $\%$ \\
\hline 1 & Hidrasi & $\begin{array}{c} \\
1.010 \\
\mathrm{~g} / \mathrm{dL}\end{array}$ & 2 & 33,3 & 2 & 33,3 \\
\hline 2 & Dehidrasi & $\begin{array}{c}1.021- \\
1.030 \\
\mathrm{~g} / \mathrm{dL} \\
\end{array}$ & 4 & 66,67 & 4 & 66,67 \\
\hline 3 & $\begin{array}{c}\text { Sangat } \\
\text { Dehidrasi }\end{array}$ & $\begin{array}{c}> \\
1.030 \\
\mathrm{~g} / \mathrm{dL}\end{array}$ & 0 & 0 & 0 & 0 \\
\hline & Jumlah & & 6 & 100 & 6 & 100 \\
\hline
\end{tabular}

1) Dilihat dari Tabel 3 , di ketahui bahwa dari 6 orang responden penelitian kelompok Air kelapa pada saat pre test , sebanyak 2 orang $(33,3 \%)$ status hidrasinya berada pada kategori hidrasi, dan sebanyak 4 orang $(66,67 \%)$ status hidrasinya berada pada kategori dehidrasi. Data tersebut menunjukkan bahwa mayoritas atlet anggota UKM Bola Basket UPI putra berada pada kategori dehidrasi.

2) Dilihat dari Tabel 3 , di ketahui bahwa dari 6 orang responden penelitian kelompok Air kelapa pada saat post test , sebanyak 2 orang $(33,3 \%)$ status hidrasinya berada pada kategori hidrasi, dan sebanyak 4 orang $(66,67 \%)$ status hidrasinya berada pada kategori dehidrasi. Data tersebut menunjukkan bahwa mayoritas atlet anggota UKM Bola Basket UPI putra berada pada kategori dehidrasi.

Tabel 4. Data Hasil Status Hidrasi Kelompok Minuman Isotonik

\begin{tabular}{|c|c|c|c|c|c|c|}
\hline \multirow[t]{2}{*}{ No } & \multirow{2}{*}{$\begin{array}{c}\text { Kategori } \\
\text { Status } \\
\text { Hidrasi }\end{array}$} & \multirow{2}{*}{$\begin{array}{c}\text { Nilai } \\
\text { Berat } \\
\text { Jenis } \\
\text { Urine }\end{array}$} & \multicolumn{2}{|c|}{$\begin{array}{l}\text { Frekuensi } \\
\text { (Pre test) }\end{array}$} & \multicolumn{2}{|c|}{$\begin{array}{l}\text { Frekuensi } \\
\text { (Post test) }\end{array}$} \\
\hline & & & $\begin{array}{c}\mathbf{F} \\
(\mathbf{n})\end{array}$ & $\%$ & $\mathbf{F}(\mathbf{n})$ & $\%$ \\
\hline 1 & Hidrasi & $\begin{array}{c}<1.010 \\
\text { g/dL }\end{array}$ & 2 & 33,3 & 3 & 50 \\
\hline 2 & Dehidrasi & $\begin{array}{c}1.021- \\
1.030 \\
\mathrm{~g} / \mathrm{dL}\end{array}$ & 4 & 66,67 & 3 & 50 \\
\hline 3 & $\begin{array}{c}\text { Sangat } \\
\text { Dehidrasi }\end{array}$ & $\begin{array}{c}>1.030 \\
\mathrm{~g} / \mathrm{dL}\end{array}$ & 0 & 0 & 0 & 0 \\
\hline & Jumlah & & 6 & 100 & 6 & 100 \\
\hline
\end{tabular}

1) Dilihat dari Tabel 4 , di ketahui bahwa dari 6 orang responden penelitian kelompok Minuman Isotonik pada saat pre test, sebanyak 2 orang $(33,3 \%)$ status hidrasinya berada pada kategori hidrasi, dan sebanyak 4 orang $(66,67 \%)$ status hidrasinya berada pada kategori dehidrasi. Data tersebut menunjukkan bahwa mayoritas atlet anggota UKM Bola Basket UPI putra berada pada kategori dehidrasi.

2) Dilihat dari Tabel 4, di ketahui bahwa dari 6 orang responden penelitian kelompok Minuman Isotonik pada saat post test, sebanyak 3 orang $(50 \%)$ status hidrasinya berada pada kategori hidrasi, dan sebanyak 3 orang $(50 \%)$ status hidrasinya berada pada kategori dehidrasi. Data tersebut menunjukkan bahwa atlet anggota UKM Bola Basket UPI putra ada yang berubah keadaan status hidrasinya yang berjumlah 1 orang. 


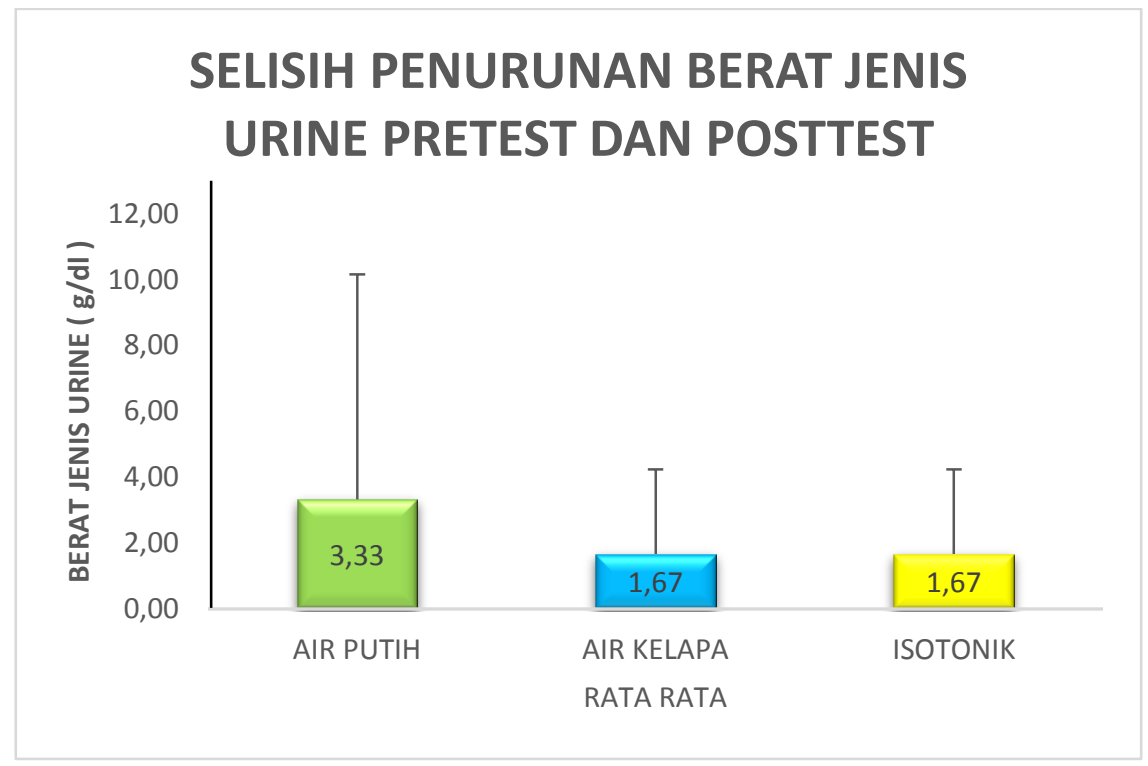

Gambar 2. Selisih Penurunan Berat Jenis Urine

Tabel 5. Uji Paired Sample T test Indeks Kelelahan

\begin{tabular}{cccccc}
\hline No & Variabel & $\begin{array}{c}\text { Nilai } \\
\mathbf{t}\end{array}$ & Sig. & $\begin{array}{c}\text { Keterang } \\
\text { an }\end{array}$ & $\begin{array}{c}\text { Kesimpu } \\
\text { lan }\end{array}$ \\
\hline $\mathbf{1}$ & Air Putih & $\begin{array}{c}4.69 \\
0\end{array}$ & 0.05 & $\begin{array}{c}\mathrm{H}_{0} \mathrm{di} \\
\text { terima }\end{array}$ & $\begin{array}{c}\text { Tidak } \\
\text { terdapat } \\
\text { perbedaa } \\
\mathrm{n}\end{array}$ \\
\hline $\mathbf{2}$ & Air Kelapa & $\begin{array}{c}3.91 \\
2\end{array}$ & 0.01 & $\begin{array}{c}\mathrm{H}_{0} \mathrm{di} \\
\text { tolak }\end{array}$ & $\begin{array}{c}\text { Terdapat } \\
\text { perbedaa } \\
\mathrm{n}\end{array}$ \\
\hline $\mathbf{3}$ & $\begin{array}{c}\text { Minuman } \\
\text { Isotonik }\end{array}$ & $\begin{array}{c}6.18 \\
5\end{array}$ & 0.02 & $\begin{array}{c}\mathrm{H}_{0} \mathrm{di} \\
\text { tolak }\end{array}$ & $\begin{array}{c}\text { Terdapat } \\
\text { perbedaa } \\
\mathrm{n}\end{array}$ \\
\hline
\end{tabular}

1) Dari Tabel 5 , di peroleh nilai $\mathrm{t}=4.690 p=$ $0.05=0.05$, maka data tersebut tidak signifikan. Yang artinya data tersebut tidak terdapat pengaruh yang signifikan dari pemberian Air Putih terhadap penurunan Indeks Kelelahan.

2) Dari Tabel 5 , di peroleh nilai $\mathrm{t}=3.912$ $p=0.011<0.05$, maka data tersebut signifikan. Yang artinya data tersebut terdapat pengaruh yang signifikan dari pemberian Air kelapa terhadap penurunan Indeks Kelelahan.

3) Dari Tabel 5 , di peroleh nilai $\mathrm{t}=6.185$ $p=0.02<0.05$, maka data tersebut signifikan. Yang artinya data tersebut terdapat pengaruh yang signifikan dari pemberian Minuman Isotonik terhadap penurunan Indeks Kelelahan.

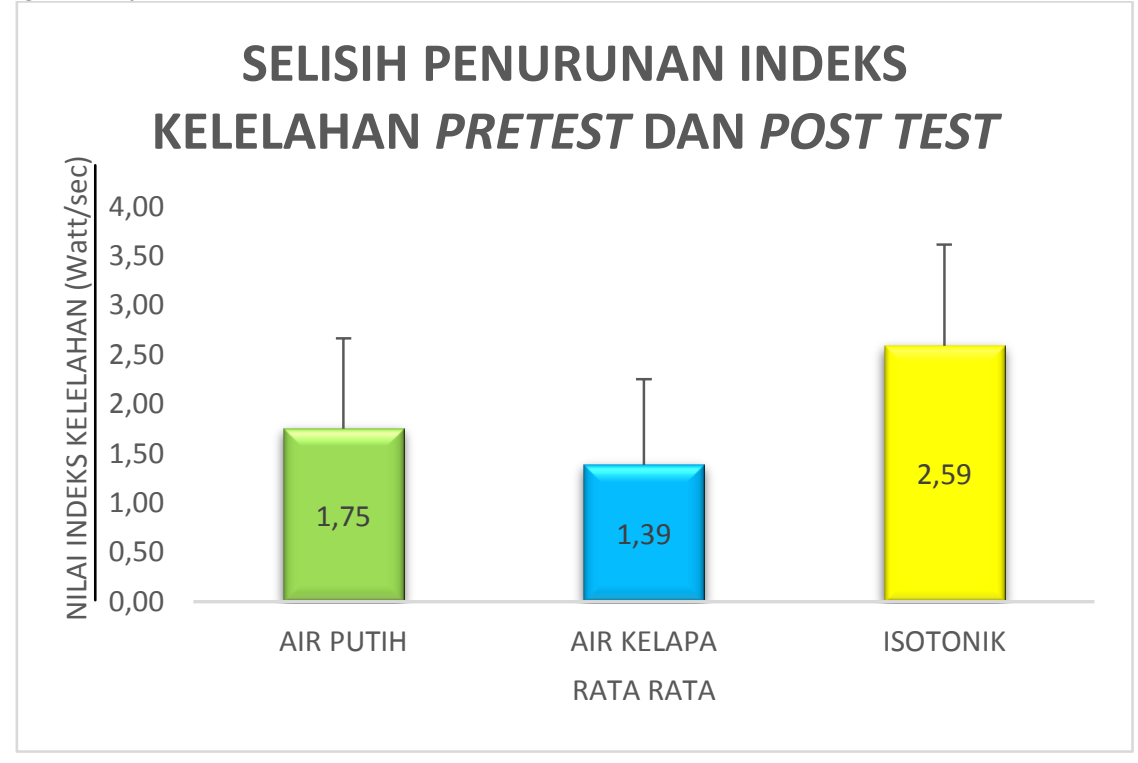

Gambar 3. Selisih Penurunan Indeks Kelelahan 
Tabel 6. Uji Paired Sample T test Data Kadar Gula Darah

\begin{tabular}{|c|c|c|c|c|c|}
\hline No & Variabel & $\begin{array}{c}\text { Nila } \\
\text { i t }\end{array}$ & Sig. & $\begin{array}{c}\text { Keteran } \\
\text { gan }\end{array}$ & $\begin{array}{c}\text { Kesimp } \\
\text { ulan }\end{array}$ \\
\hline 1 & Air Putih & $\begin{array}{c}0.25 \\
9\end{array}$ & $\begin{array}{c}0.8 \\
06\end{array}$ & $\begin{array}{l}\mathrm{H}_{0} \mathrm{di} \\
\text { terima }\end{array}$ & \begin{tabular}{l}
\multicolumn{1}{c}{ Tidak } \\
terdapat \\
perbedaan
\end{tabular} \\
\hline 2 & Air Kelapa & $\begin{array}{c}- \\
0.89 \\
6\end{array}$ & $\begin{array}{c}0.4 \\
11\end{array}$ & $\begin{array}{l}\mathrm{H}_{0} \mathrm{di} \\
\text { terima }\end{array}$ & \begin{tabular}{l}
\multicolumn{1}{c}{ Tidak } \\
terdapat \\
perbedaan
\end{tabular} \\
\hline 3 & $\begin{array}{l}\text { Minuman } \\
\text { Isotonik }\end{array}$ & $\begin{array}{c}3.34 \\
0\end{array}$ & $\begin{array}{c}0.2 \\
1\end{array}$ & $\begin{array}{c}\mathrm{H}_{0} \\
\text { diterima }\end{array}$ & $\begin{array}{c}\text { Tidak } \\
\text { Terdapat } \\
\text { perbedaan }\end{array}$ \\
\hline
\end{tabular}

1) Dari Tabel 6, di peroleh nilai $t=0.259$ $p=0.806>0.05$, maka data tersebut tidak signifikan. Yang artinya data tersebut tidak terdapat pengaruh yang signifikan dari pemberian Air Putih terhadap penurunan Kadar Gula Darah .

2) Dari Tabel 6, di peroleh nilai $\mathrm{t}=-.896$ $p=0.411>0.05$, maka data tersebut tidak signifikan. Yang artinya data tersebut tidak terdapat pengaruh yang signifikan dari pemberian Air kelapa terhadap penurunan Kadar Gula Darah .

3) Dari Tabel 6, di peroleh nilai $\mathrm{t}=3.340$ $p=0.21>0.05$, maka data tersebut tidak signifikan. Yang artinya data tersebut tidak terdapat pengaruh yang signifikan dari pemberian Minuman Isotonik terhadap penurunan Kadar Gula Darah.
Tabel 7. Uji Anova Indeks Kelelahan

\begin{tabular}{ccccc}
\hline Variabel & F & Sig. & $\begin{array}{c}\text { Keputus } \\
\text { an }\end{array}$ & $\begin{array}{c}\text { Kesimpu } \\
\text { lan }\end{array}$ \\
\hline Tes Indeks & 2.6 & 0.1 & $\mathrm{H}_{0}$ di & $\begin{array}{c}\text { Tidak } \\
\text { terdapat } \\
\text { Kelelahan }\end{array}$ \\
& 07 & 07 & terima & perbedaan \\
\hline
\end{tabular}

Dari Tabel 7 , di peroleh nilai $\mathrm{F}=2.607, p=$ $0.107>0.05$ maka $\mathrm{H}_{0}$ diterima. Tidak terdapat perbedaan yang signifikan keadaan Indeks Kelelahan pemain basket menurut pemberian jenis minuman.

Tabel 8. Uji Anova Kadar Gula Darah

\begin{tabular}{ccccc}
\hline Variabel & F & Sig. & $\begin{array}{c}\text { Keputu } \\
\text { san }\end{array}$ & $\begin{array}{c}\text { Kesimpu } \\
\text { lan }\end{array}$ \\
\hline $\begin{array}{c}\text { Tes Kadar Gula } \\
\text { Darah }\end{array}$ & 5.4 & 0.0 & $\mathrm{H}_{0}$ di & Terdapat \\
tolak & perbedaan \\
\hline
\end{tabular}

Dari Tabel 8 , di peroleh nilai $\mathrm{F}=5.473$, $p=0.016<0.05$ maka $\mathrm{H}_{0}$ ditolak. Terdapat perbedaan yang signifikan keadaan Kadar Gula Darah pemain basket menurut pemberian jenis minuman.

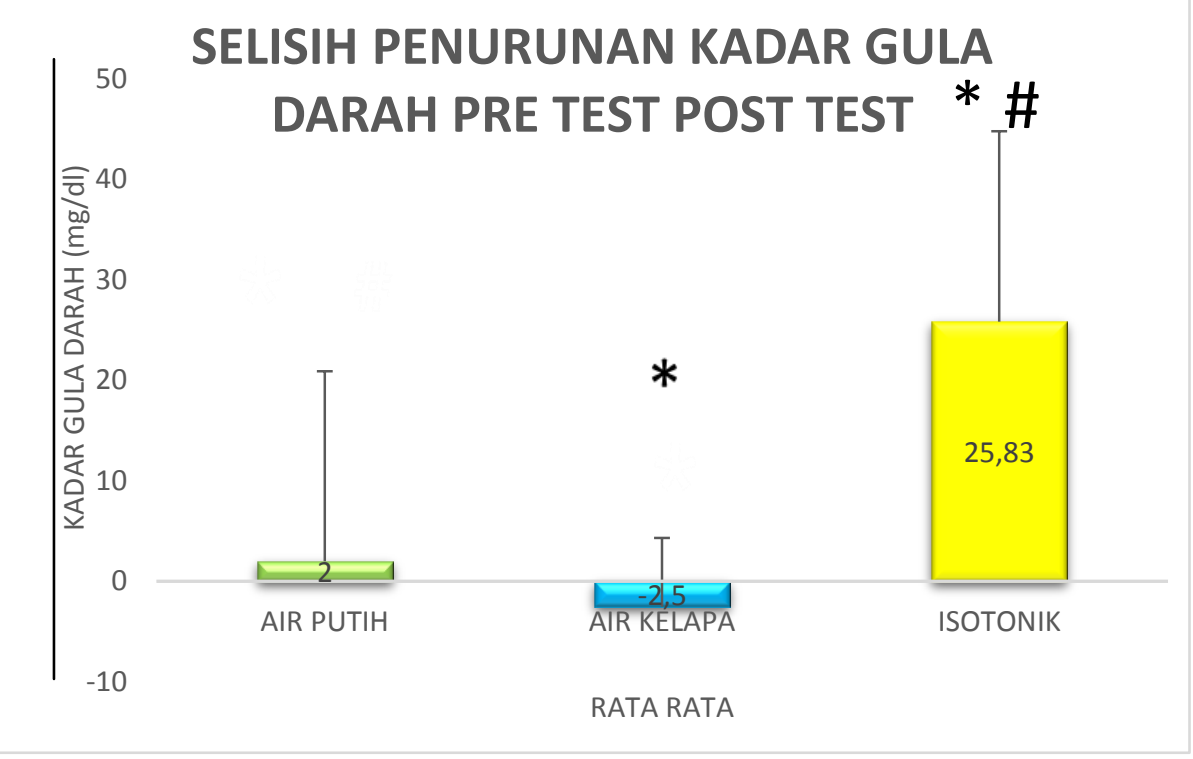

Keterangan :

* : signifikan Air kelapa dan minuman isotonik dengan Air Putih.

\# : signifikan minuman isotonik dengan Air kelapa 


\section{DISKUSI}

Berdasarkan hasil pengolahan data dan analisis data dari ketiga sampel yaitu kelompok Air Putih, Air kelapa dan Minuman Isotonik kepada anggota UKM Bola Basket UPI putra, peneliti memperoleh beberapa temuan di antaranya :Status hidrasi yang di lihat dari perubahan warna urine dan berat jenis urine, kelompok yang di beri Air kelapa dan Minuman Isotonik menunjukkan bahwa mayoritas atlet anggota UKM Bola Basket UPI putra berada pada kategori dehidrasi. Dari 3 jenis permberian minuman, kelompok eksperimen Air Kelapa dan Minuman Isotonic di bandingkan dari hasil pre test dan post test data menunjukkan bahwa tidak ada perubahan status hidrasi dan tetap pada kategori dehidrasi. Sedangkan kelompok yang diberi Air putih sebagai kelompok kontrol mengalami perubahan status hidrasi dari kategori dehidrasi menjadi hidrasi.

Terdapat pengaruh yang signifikan keadaan Indeks Kelelahan menurut pemberian jenis minuman Air kelapa dan Minuman Isotonik pada pemain Basket UKM BOLA BASKET UPI putra. Hal ini bisa terjadi karena di lihat dari kandungannya, jenis minuman yang termasuk minuman olahraga ini yaitu Air kelapa dan Minuman Isotonik mengandung karbohidrat, protein, kalium, natrium, glukosa yang bisa menunda kelelahan. "Karbohidrat sering dimasukkan dalam minuman olahraga untuk dijadikan sumber energi. Penyediaan energi karbohidrat terbukti menunda kelelahan “12. Terdapat perbedaan yang signifikan keadaan Kadar Gula Darah pemain basket menurut pemberian jenis minuman ( Air kelapa, Minuman Isotonik dan Air putih ) pada pemain Basket UKM BOLA BASKET UPI putra. Kadar gula darah kelompok yang di beri Minuman Isotonik mengalami penurunan yang signifikan dibandingkan ke dua kelompok lainnya yaitu Air putih dan Air kelapa.

\section{KESIMPULAN}

Berdasarkan pengolahan data dan analisis data peneliti dapat memberikan kesimpulan sebagai berikut :

1. Tidak terdapat pengaruh yang signifikan perubahan status hidrasi di lihat dari warna urine dan berat jenis urine pada pemain Basket UKM BOLA BASKET UPI putra.

2. Terdapat pengaruh yang signifikan keadaan Indeks Kelelahan menurut pemberian jenis minuman Air kelapa dan Minuman Isotonik pada pemain Basket UKM BOLA BASKET

UPI putra.

3. Tidak terdapat pengaruh yang signifikan keadaan Kadar Gula Darah menurut pemberian jenis minuman ( Air kelapa, Minuman Isotonik dan Air putih ) pada pemain Basket UKM BOLA BASKET UPI putra.

4. Tidak terdapat perbedaan yang signifikan keadaan Indeks Kelelahan pemain basket menurut pemberian jenis minuman ( Air kelapa, Minuman Isotonik dan Air putih ) pada pemain Basket UKM BOLA BASKET UPI putra.

5. Terdapat perbedaan yang signifikan keadaan Kadar Gula Darah pemain basket menurut pemberian jenis minuman ( Air kelapa, Minuman Isotonik dan Air putih) pada pemain Basket UKM BOLA BASKET UPI putra.

\section{DAFTAR PUSTAKA}

1. Sumiyarsono D. Teori dan Metodologi Melatih Fisik Bolabasket. Yogyakarta. Fakultas Ilmu Keolahragaan. Universitas Negeri Yogyakarta. 2006.

2. Manz F, Wentz A. The Importance of Good Hydration for the Prevention of Chronic Disease. Nutr Rev. 2005;63(2):S2-5.

3. Dougherty KA, Baker LB, Chow M, Kenney WL. Two percent dehydration impairs and six percent carbohydrate drink improves boys basketball skills. Med Sci in Sports Exerc. 2016;38(9): 1650-1658.

4. Maughan dan Murray. Minuman Olah Raga, Isotonik dan Energi. Availablefrom:http://finance.dir.groups.ya hoo.com/group/FoodtechIndonesia /message/564. 2001.

5. American College of Sports Medicine, Sawka MN, Burke LM, Eichner ER, Maughan RJ, Montain SJ, Stachenfeld NS. American College of Sports Medicine: Exercise and fluid replacement. Med Sci Sports Exerc. 2007;39(2):377390.

6. Murray B. Hydration and physical performance. $J$ Am Coll of Nutr. 2007;26(Suppl 5):542S-548S.

7. Shirreffs SM. Markers of Hydration Status. Eur J Clin Nutr. 2003;57(Suppl 2):S6-9 
8. Coyle EF. Fluid and Fuel intake during excercise. J Sport Sci. 2004;22(1):39-55

9. Atmaja IM. Pemberian Minuman Air Kelapa Muda Lebih Cepat Memulihkan Denyut Nadi Daripada Pemberian Minuman Isotonik dan Teh Manis Pada Pesilat Siswa SMP Dwijendra Denpasar. (tesis). Denpasar: Universitas Udayana. 2009.
10. Badan Standar Nasional. Standar Nasional Indonesia (SNI) 01-4452-1998. Minuman Isotonik. BSN. 1998.

11. Armstrong LE. Performing in Extreme Environments. Champaign IL: Human Kinetics. 2008.

12. Brouns F, Senden J, Beckers EJ, Saris WH. Osmolarity does not affect the gastric emptying rate of oral rehydration solutions. JPEN J Parenter Enteral Nutr. 1995;19(5):403-406. 